\title{
Research of the effect of a biological preparation based on the association of nitrogen-fixing bacteria on a legume culture
}

Martynenko V.V., Rysbek A.B., Kurmanbayev A.A., Baigonusova Zh.A.

RSE "National Center for Biotechnology" SC MES RK, Nur-Sultan, Republic of Kazakhstan

E-mail: vitalya2497@gmail.com

Key message. A field experiment with a biological preparation based on the association of nitrogen-fixing bacteria was carried out. As a result, the biological preparation had a positive effect on germination, length and vegetative mass of peas. Keywords: biological preparation, nitrogen-fixing bacteria, peas, bacterial associations, productivity

Bacterial fertilizers allow you to take the natural potential of environment to improve mineral nutrition and plant protection. They are completely safe for humans and the environment, exclude environmental risks and make it possible to reduce the doses of applied agrochemicals and mineral fertilizers. The goal of this work is to create a biological product that increases the yield of legumes.

The cultivation of strains of nitrogen-fixing bacteria was carried out in a modified Burke's medium on a rotary shaker at 180 $200 \mathrm{rpm}$ and $28{ }^{\circ} \mathrm{C}$ for 48 hours [1]. Field experiments were laid on stubble of field № 5. Soft spring wheat was the predecessor. Field preparation and implementation of experiments are carried out according to the relevant recommendations of KazNIIZH [2-3], with some additions and changes accepted at the SPC GF of A.I. Baraev.

The composition of the biological preparation for legumes included an association of microorganisms (Rhizobium sp. strain Rh-1 + Azotobacter chroococcum strain Az $34+$ Agrobacterium sp. strain Az $6+$ Agrobacterium sp. strain Az 4). The ratio in the association is 7: 1: 1: 1, which ensures its stable work due to the symbiotic relationship of microorganisms.

To assess the effectiveness of biological preparation was conducted experiment on the fields of the LLP SPC of grain farming named after A.I. Baraev on an area of $300,000 \mathrm{~m}^{2}$. For pre-sowing treatment, 10 liters of suspension concentrate $\left(10^{9} \mathrm{CFU} / \mathrm{ml}\right)$ were used. The biological preparation was diluted five times to treat $6000 \mathrm{~kg}$ of pea seeds of the "Aksai Usatii-55" variety.

The growing season for peas in the field experiment was 86 days on average. The period from germination to flowering was 36-37 days for the studied samples. In the experimental field, there was not a complete harvest yet, because the ripening of peas was delayed due to the dry of 1-2 decades. However, in the experiment and control variants maturation was uneven.

Despite the unfavorable weather and soil conditions, the biological preparation provided an increase in the grain yield of peas of the "Aksaysky Usatii 55" variety by 1.38 centner/ha compared to the control variant. The structural indicators of pea plants also demonstrate the effectiveness of the preparation: early flowering, the plant height is $15.4 \mathrm{~cm}$ higher than in the control variant; the number of seeds per plant was 141.03, and the weight of seeds per plant was $198.2 \mathrm{~g}$; while in control - 116.38 pcs. with weight of $190.2 \mathrm{~g}$.

Thus, according to the results of the field experiment, the biological preparation provided the grain yield of peas equal to 13.00 centner/ha, which exceeded the control variant without treatment by $12 \%$.

This work implemented within the BR06349586 project, funded by the Ministry of Agriculture of the Republic of Kazakhstan.

1. Ibatullina R.P. Ekologicheskie aspekty primeneniya biopreparatov v Respublike Tatarstan, avtoref. kand. biol. nauk: 03.02.08. - Kazan', 2011. - 24 s.

2. Sistema zemledeliya opytnogo hozyajstva / VNIIZKH im. A.I. Baraeva. - SHortandy, 1986 g. - S. 4-6.

3. Metody izucheniya kollekcii zernobobovyh kul'tur. - L., - 1968. - $173 \mathrm{~s}$. 